\title{
Volume and Territorial Distribution of the Czech Republic's Official Development Assistance Flows to Least Developed Countries
}

\section{Eva Kovářová ${ }^{1}$}

\begin{abstract}
Official Development Assistance (ODA) is considered one of the most important external resources of finance that can contribute to sustainable development in the Least Developed Countries (LDCs). The Czech Republic, as an official donor country, should spend on ODA, with respect to the EU and national targets, at least $0.33 \%$ of its GNI by the year 2030. Eradication of poverty in the context of sustainable development belongs to the long-term priorities of the Czech foreign development cooperation, and thus the Czech Republic considers some LDCs, which population is more likely to live in extreme poverty, the priority partner countries. Paper evaluated fundamental trends of the Czech Republic's ODA flows to LDCs; compared them with the trends identified for the collective flows of allDAC members and for the flows of its four selected members (Hungary, Poland, Slovakia, Slovenia). Identified trends of Czech ODA flows showed clearly that Czech Republic did not meet official commitments regarding the volume of ODA and that level of fragmentation of the ODA flows to LCDs was quite high when these trends were examined during the period 2000-2018. However, the Czech Republic's development cooperation policy did not differ markedly from the policies of the other four ODA donors. Any significant differences were identified when the fundamental trends of Czech ODA flows were compared with those ones identified for Hungary, Poland, Slovakia and Slovenia.
\end{abstract}

Keywords: Czech Republic, Least Developed Countries, Official Development Assistance, Sustainable Development

JEL Classification: F35, F43, F63

Received: 7 September 2020 /Accepted: 23 February 2021 /Sent for Publication: 16 March 2021

\section{Introduction}

Official Development Assistance (ODA) represents one of the most important external resources of finance that can help the Least Developed Countries (LDCs) to develop their economies and increase the standard of living of its inhabitants. These countries are identified as being highly disadvantaged in their development process because of structural,

\footnotetext{
${ }^{1}$ VŠB - Technical University of Ostrava, Faculty of Economics, Department of Public Economics, Czech Republic. Email: eva.kovarova@ vsb.cz, ORCID: 0000-0002-1548-6889.

C 2021 by the authors; licensee Review of Economic Perspectives / Národohospodárský obzor, Masaryk University, Faculty of Economics and Administration, Brno, Czech Republic. This article is an open access article distributed under the tems and conditions of the Creative Commons Attribution 3.0 license, Attribution -Non Commercial - No Derivatives.
} 
historical and geographical reasons. LDCs are less involved in the global economy than their need with respect to their further development. Currently, 880 million people live in 47 LDCs, which produce only 2 percent of the world GDP and 1 percent of the world trade (UNCTAD, 2020). Because of the countries' underdevelopment, their inhabita nts are more likely to live in extreme poverty accompanied by low human well-being than the rest of the world population.

Lack of domestic financial resources is considered one of the most serious barriers for the sustainable development in LDCs. In 2015-2017, the resource gap (defined as the difference between domestic savings and gross fixed capital formation) for all LDCs reached $8 \%$ of their GDP. For nearly half of the LDCs, the gap was above $15 \%$ of their GDP. However, in 2018, the LDCs received collectively only 27 percent of total ODA flows, and at the same time, LDCs faced declining foreign investment inflows, which declined between years 2015 and 2018 by $37 \%$ (United Nations, 2019).

Since 2013, the Czech Republic has been a member of the Development Assistance Committee (DAC) of the Organisation of the Economic Co-operation and Development (OECD) and belongs thus to countries with so-called emerging donor status. The main aim of the Czech development policy is defined as the contribution to the eradication of poverty in the context of susta inable development (Act on Development Cooperation and Humanitarian Aid), respectively promotion of the stability and fostering of the potential for sustainable development in partner countries (Development Cooperation Strategy of the Czech Republic 2018-2030). However, similarly to most other DAC countries, the Czech Republic does not meet neither the official internationally declared target concerning the ODA volume $(0.70 \%$ of GNI) nor the national target to spend on ODA $0.17 \%$ of GNI by the year 2020. There is no indication that the final ODA/GNI ratio defined at $0.33 \%$ will be met by the year 2030 .

Czech development a ssistance has been reviewed and examined by several research studies in recent years, when some are quite critical, for instance: Horký (2011) stated that Czech development cooperation has good direction, but the efforts are inadequate; Krylová, Syrovátka and Opršal(2012) were sceptic about meeting the recommended volumes of ODA by the Czech Republic; Harmáček, Syrovátka, and Opršal (2017) showed that the Czech Republic spent on average more ODA in countries related to the former Council for Mutual Economic Assistance and that higher volume of exports implied higher volume of ODA. Syrovátka and Krylová (2012) calculated the aid component of the Commitment to Development Index for the Czech Republic and concluded that to improve its score the country would need to increase aid quantity as well as quality, including lower fragmentation and a higher share of aid given to poor and well-governed countries.

No study focuses exactly on the analysis of the Czech ODA flows to LDCs and their territorial distribution a mong these countries. Therefore, the aim of the paper is to evaluate fundamental trends of the Czech Republic's ODA flows to LDCs; to compare them with the trends identified for collective flows of all DAC countries and forflows of its four selected members (Hungary, Poland, Slovakia, Slovenia). The analysis is focused on the period 2000-2018. The statistical analysis deals with the data taken from the public data- 
bases of the Organisation for Economic Co-operation and Development. They are processed using the standard methods of explanatory statistics and the updated HerfindahlHirschman Market Concentration Index (ODA flows are used instead of trade flows).

The paperis structured as follows:

(1) The paper is opened with a literature review introducing the definition of international and EU commitments concerning the volume of ODA, and the relation between ODA flows and economic growth, resp. reduction of extreme poverty.

(2) The methodology of the analysis is explained, where special attention is paid to OECD data concerning the ODA spending.

(3) The fundamental trends of the total ODA flows are identified and evaluated for the Czech Republic. They are compared with those identified for Hungary, Poland, Slovakia and Slovenia, and all DAC members' collective flows.

(4) Volume and territorial distribution of ODA flows allocated to LDCs are examined when the fragmentation of ODA flows is evaluated using the Herfindahl-Hirschman Market Concentration Index. The level of Czech ODA flows fragmentation is then compared with those ones identified for Hungary, Poland, Slovakia and Slovenia.

\section{Literature review}

Because of insufficient domestic financialresources, LDCs are heavily dependent on external financial inflows from more developed countries, when the Official Development Assistance (ODA) is traditionally regarded as an important external resource of finance for the investment to fixed capital related to sustainable development, and a mean that can help poor LDCs countries to end the poverty trap. Therefore, the global political effort is focused on the increase of the ODA flows. At the same time, the importance of the contribution of ODA to economic growth and poverty reduction is examined in many research studies.

\section{International commitments to official development assistance}

The DAC OECD has represented an important internationalforum based on the cooperation of the major donor countries since its formation in 1961. This Committee is responsible for the first definition of the ODA that was introduced in 1969 when the ODA was adopted as the gold standard of foreign aid. Today, the DAC OECD has got thirty members, when the European Union is represented as one member, and then twenty EU member states have their own membership, including also five members accessing the EU in 2004 - Czech Republic, Hungary, Poland, Slovak Republic, Slovenia.

One of the main responsibilities of the DAC OECD is to monitor the ODA flows with respect to the actual ODA definition. Data on ODA are based on the definition that understands ODA as the flows to partner countries listed on the DAC list of ODA recipients and to multilateral development institutions, which are (a) provided by official agencies, including state and local governments, or by their executive agencies; and (b) concessional (i.e. grants and soft loans) and administered with the promotion of the economic development and welfare of developing countries as the main objective (OECD, 2020a). 
Therefore, two basic forms of ODA are recognized - grants and loans. By the end of the year 2017, statistics of ODA flows were based on the cash or flow basis methodology, which means that grants and loans were valued in the same way. Since the year 2018, ODA grant-equivalent methodology is used to monitor the ODA spending to show the difference in donors' efforts when the grants and loans are compared (OECD, 2020b). Use of the grant-equivalent methodology means that only the "grantportion" of the loan, i.e., the amount "given" by lending below market rates, counts as ODA (OECD, 2020c).

The first list of Least Developed Countries (LDCs), which indicates countries staying behind the others in terms of their development, was introduced by the United Nations Conference on Trade and Development(UNCTAD) in 1971. The list of LDCs is reviewed every three years, and currently, it contains 47 countries (33 in Africa, 9 in Asia, 4 in the Pacific and 1 in the Caribbean). To be included into the list, countries have to meet criteria defined by the United Nations, when these criteria concern level of national income, and indexes of human assets and economic and environmental vulnerability.

In the 1960s, the first official targets defining the volume of development aid, which the developed countries had to provide to less developed ones, were introduced, too. Current target - to provide on ODA at least $0.70 \%$ of GNI was adopted by the General Assembly of the United Nations by the Resolution A/RES/2626(XXV) in 1970. Despite many proposals for the review of this target, it is still applied and commit donor countries to spend this amount of their GNI on ODA. Because of the generally recognized importance of ODA for LDCs, the LDCs-specific target for aid allocation was declared in the Substantial New Programme of Action for LDCs of 1981, when donor countries committed themselves to provide ODA equivalent to $0.15-0.20 \%$ of their GNI to LDCs (United Nations, 2019). Since then, both objectives have been reaffirmed by many off icial declarations, when the latest ones are:

- The Programme of Action for the Least Developed Countries for the decade 20112020, which also committed developed countries to ensure enhanced financial resources and their effective use for the LDCs. It proposed a renewed and strengthened partnership for development. ODA was ranked among eight priorities when the Programme called for financial resources' mobilization for development and capacity building (United Nations, 2011,p. 11).

- The 2030 Agenda for Sustainable Development, which called for strengthened global solidarity, focused on the world poorest and most vulnerable with the participation of all countries, all stakeholders and all people. The 2030 Agenda explained that the important use of ODA was to catalyse additional resource mobilization from other sources, including public as well as private sources (United Nations, 2015, p. 11).

- The Addis Ababa Action Agenda, in which signatories appreciated the increase in the volume of ODA since 2002, but they pointed out the fact that many countries still did not meet their ODA commitments and that the ODA flows to LDCs declined despite the greatest importance of ODA for these category countries (United Nations, 2015).

- The New European Consensus on Development that committed the EU to spend collectively on ODA at least $0.70 \%$ of GNI within the timeframe of the 2030 
Agenda for Sustainable Development, and to allocate collectively to LDCs as the ODA at least $0.20 \%$ of GNI by the year 2030 (European Commission, 2017). The European Union ODA pledge is based on individual commitments of its member states reaffirmed in 2015. Member states joining EU before the year 2002 committed themselves to achieve the $0.7 \%$ ODA/GNI target, while members states joining the EU after the year 2003 (called further as the EU-13 members) committed themselves to strive to increase their ODA/GNI ratio (European Union, 2018).

\section{Official development assistance as the engine of economic growth and poverty reduc- tion}

One of the first studies, which highlighted the importance of externalassistance in meeting capital requirements of the poor developing countries, was published already in 1967 (Chenery, 1967). Since then, numerous studies were published to show whether the ODA flows (or simply foreign aid) are engines for the economic and social development connected with the poverty reduction in LDCs. The early models were based on HarrodDomar growth models (Mallik, 2008), when the most common ones were the two-gap models. The two-gap modelexplains long-term growth dynamics in developing countries and can be specified as the Harrod and Domar models updated for the open and developing economies. It deals with two gaps: (1) gap between domestic savings and investment needs, (2) gap between export revenues and imports needed for development, when both gaps can be bridged by foreign aid (Bende, Löwenstein, 2005). In general, the model assumes that most poor developing countries have ina dequate domestic savings and that foreign aid can supplement them if it is directed to investment (Mallik, 2008).

The relation between foreign aid and economic growth is one of the commonly discussed development topics amongst scholars. However, it is hard to find any consensus on the direction and intensity of this relationship because studies dealing with different groups of developing countries usually bring different findings. For instance, compare findings of: Izevbigie, Isikhuemen, Ogbeifun (2020); Suphian, Kim (2016); Mallik (2008); Dalgaard, Hansen, Tarp (2004); Collier, Dollar (2002); Chenery (1967). Relation between development assistance and economic growth is also examined in consequence of the impact of foreign aid on poverty reduction, as poverty reduction is the most commonly cited core objective of support aid programs (Collier, Dollar, 2002).

Foreign aid is considered as the resource of finance that can help low-income developing countries to end the poverty trap, they are in some cases caught in. The poverty trap occurs when poverty has effects that act as causes of poverty (Gore, 2003). To end the poverty trap, LDCs and other low-income developing countries need to invest in such necessities as health, education, or ba sic infra structure (Sachs, McArthur, 2005). Therefore, external assistance or foreign aid are regarded as means that can help to reduce extreme poverty or to end the poverty trap; see for instance: Sachs (2005); Collier, Dollar (2002); Mallik (2008); Dalga ard, Hansen, Tarp (2004).

The importance of foreign aid for the improvement of the living situation of the poor individuals is emphasised also by Easterly, who is generally regard ed as a critic of development assistance, which he considers a mistake. He claim ed that foreign aid could have financed the needs related to basic necessities and basic infrastructure, to the improve- 
ment of the poor people's opportunities, and it should not be aimed to develop and transform the whole poor societies (Easterly, 2007). Development aid provided in the form of grants and loans for a long time is criticized by Moyo (in Moyo, Myers, 2010) too. She argued that a constant stream of money can protect inefficient governments in aid receiving countries and that it can promote corruption there. She explained that as a result of long-term aid, governments of the aid receiving countries were less responsible in the provision of public goods (Moyo, Myers, 2010). Sachs and McArthur (2005, p. 349) explained that when extreme poverty would be reduced with the support of external assistance, countries could begin to achieve their self-sustaining economic growth. Sachs (2012) expected that ODA will have a continuing role for low-income countries during the period of years 2015-2030, but he also expected that the role of aid would decline when today's low-income countries reach the middle-income status (Sachs, 2012). The latest UNCTAD analysis of the LDCs showed that (1) the importance of aid flows relative to economic variables has been on a steady decline since 2003; but (2) ODA played a key role in the financing of sustainable development there (United Nations, 2019).

Some preconditions for the impact of ODA on the reduction of poverty are stated by above-cited scholars when the most common ones are related to the quality of policies and governance in aid receiving countries. For instance, Sachs et al. (2004) spoke about good governance, Mosley, Hudson and Verschoor (2004) suggested allocating aid to countries with good micro and marco policies. It seems that the same preconditions are emphasized when the impact of foreign aid on economic growth is considered. Collier and Dollar (2002) showed that donors could affect economic growth through aid allocation, and then growth had an impact on the poverty reduction. However, they recommended allocating aid to countries with large amounts of poor people and good policies. Mallik (2008) showed that good policies are the key factor for the positive impact of aid on economic growth when he examined the relationship between aid and economic growth in six African countries. He argued that the negative effect, which he identified, was related to bad policies. He also pointed out the reality that foreign aid was not used for investment in many cases, rather it was used for humanitarian purposes.

\section{Methodology}

The a nalysis focuses on official development a ssistance flows from the Czech Republic to the Least Developed Countries during the period 2000-2018. The aim of the paper is to evaluate fundamental trends of the Czech Republic's ODA flows to LDCs; to compare them with the trends identified for collective flows of all DAC members and for flows of its four selected members (Hungary, Poland, Slovakia, Slovenia).

The analysis is divided into two parts:

(1) First part: The fundamental trends of Czech ODA flows are identified and interpreted. They are compared with the trends identified for the collective flows of all DAC members and for the flows of selected four DAC members. Hungary, Poland, Slovakia and Slovenia are chosen to be compared with the Czech Republic because they are the only ones of the EU-13 member states that are also the DAC members, and thus they are committed to the same international and European commitments as the Czech Republic. 
Within the first part of the analysis, attention is paid to: (1) totalnet ODA flows; (2) share of ODA flows to LDCs on total net ODA flows; (3) fulfilment of the targets concerning the volume of the ODA as the share on GNI; (4) yearover year absolute changes of the ODA flows.

(2) Second part: The volume and territorial distribution of Czech ODA flows to LDCs are examined, when the territorial allocation of ODA to LDCs is evaluated using the updated Herfindahl-Hirschman Market Concentration Index (HHI) introduced by the World Bank (2013), when the ODA flows are used instead of trade flows. Founded results are compared with selected four other DAC members. HHI is calculated as follows:

$$
H H I=\frac{\sum_{j=1}^{n_{i}}\left(\frac{x_{i j}}{X_{i}}\right)-\frac{1}{n_{i}}}{1-\frac{1}{n_{i}}}
$$

Where $X$ is the total volume of ODA flows from a country $I$ to all LDCs, $x$ is the volume of ODA flows from country $i$ to partner $\operatorname{LDC} j$, and $n$ is the number of the LDCs. Number of LDCs included into the a nalysis was changed during the analysed period in this way: $2000-2002 n=49 ; 2003-2007 n=50$ (Timor-Leste obtained LDC status); 2008-2011 $n=49$ (Cabo Verde left the LDCs in 2007); $2012 n=48$ (Maldives left LDCs); 2013-2014 $n=49$ (South Sudan obtained LDC status); 2015-2017 $n=48$ (Samoa left LDCs in 2014); $2018 n=47$ (Equatorial Guinea left LDCs in 2017); when countries graduating from the LDCs list are included into the analysis also in the year of their graduation.

To evaluate the main results of the statistical analysis, five research hypotheses are formulated, which are stated as follows:

(1) The Czech Republic made progress in meeting the national, EU and international targets concerning the volume of ODA.

(2) The Czech Republic spent on ODA a higherpercentage of its GNI than four other countries.

(3) The LDCs belonged to priority partner countries defined with strategic documents framing the Czech development cooperation.

(4) The Czech Republic followed the recommendations to lower the level of the ODA flows fragmentation.

(5) The level of fragmentation of the Czech ODA flows to LDCs was lower than the level of the four other countries.

Methods of standard explanatory statistics are used in the analysis. The analysis deals with the data on ODA taken from the public data sets of the Organisation for Economic Co-operation and Development (2020c, 2020d). When the volume of total net ODA and total ODA allocations to LDCs are analysed, data were taken from the OECD dataset called Net ODA. This dataset reports volume of ODA (bilateral as well as multilateral) net disbursements and its geographical allocation for all DAC members. Analysis of the territorial distribution of ODA flows deals with data taken from the OECD data set called Aid (ODA) disbursements to countries and regions. 


\section{Interpretation of the results and findings}

The Czech Republic has been a member of the Development Assistance Committee (DAC) of the Organisation of the Economic Co-operation and Development (OECD) and belongs thus to countries with so-called emerging donor status. It is committed as a member of the United Nations with the internationaltarget and as a member of the European Union by the European target concerning the volume of ODA and volume of ODA allocated to the LDCs. However, the Czech Republic can follow its own thematic and territorial priorities of the development cooperation, when the Act defines its main objectives on Development Cooperation and Humanitarian Aid and strategic documents framing priorities of the Czech development cooperation for a certain period of time.

\section{Fundamental trends of the Czech ODA flows with regard to international and $E U$ com- mitments}

The Czech Republic introduced its first system of development cooperation in the mid 1990 s when the principles of foreign aid were adopted in 1995. Within the first twelve years, a system of help was fragmented, lacking coherence and transparency (Slá dková, 2011; Krylová, Syrovátka, Opršal, 2012). The first experience with foreign development aid was evaluated in 2001, and this analysis opened space for political and expert discussions. As a result, the first strategic document specifying Czech development cooperation and respecting the commitments related to the Millennium Development Goals Agenda, titled as the Concept of Foreign Development Aid of the Czech Republic was introduced for the period 2002-2007. Reduction of poverty through the economic and social sustainable development was stated as the framing objective (Czech Republic, Ministry of Foreign Affairs, 2001,p. 3).

In 2004, new principles of foreign development cooperation were introduced, but its main systematic patterns persisted. In 2007, the DAC Special Peer Review of the Czech development cooperation was issued, following the Czech initiative in this field. This Peer Review led to the transformation of the Czech ODA system that was finished in 2010, when the Act on Development Cooperation and Humanitarian Aid, and the next Strategy of the Development Cooperation for the period 2010-2017 were adopted. They launched a new, more efficient system of development cooperation, based on recognized weaknesses, such as high number of priority countries. Main objective of the development cooperation was modified slightly, and was defined as the eradication of poverty, promotion of security and prosperity through the effective partnership were included a mong the development cooperation objectives (Czech Republic, Ministry of Foreign Affairs, 2010, p. 6). Strategy confirmed that the Czech Republic was aware of in ternational commitments concerning the volume of ODA, and at the same time, it declared stabilization of the ODA volume at $0.11 \%$ of GNI and promised to increase ODA annually by $0.01 \%$ of GNI from the time being. Since 2013, the Czech Republic has been a mem ber of the DAC OECD and belongs thus to the most important donors of ODA.

In 2016, the Czech Republic received the second Peer Review of its development cooperation prepared by the OECD. It recommended to Czech officials to include the global dimension of the United Nations 2030 Agenda for Sustainable Development into national plans and increase the quality and impact of the aid, especially in terms of the reduced number of priority partner countries and themes. In 2017, the new Development Cooperation Strategy of the Czech Republic 2018-2030 was adopted in reaction to the 2030 
Agenda for Sustainable Development. It introduced the core objective of the Czech development cooperation and humanitarian aid that was defined as to contribute - using its capacities and experience and in line with international commitments - to building a stable, secure, inclusive, prosperous and sustainable world and to strengthen its position within it (Czech Republic, Ministry of Foreign Affairs, 2017,p. 8). The Strategy declared that cooperation would be focused in a balanced way on cooperation with low-income countries (LDCs) as well as with middle-income countries, which enabled to meet priorities of the 2030 Agenda as well as to use own experience with transformation.

Despite political declarations, during the period 2000-2018, the Czech Republic met neither the international and European nor its national target, regarding the volume of ODA. A significant increase of the ODA/GNI ratio is observed especially in the first years of the analysed period (between years 2000-2003) and between years 2015 and 2016. This finding means rejection of the first research hypothesis. See Figure1.

Figure 1. Fulfilment of the ODA targets by the Czech Republic (defined as ODA/GNI ratio)

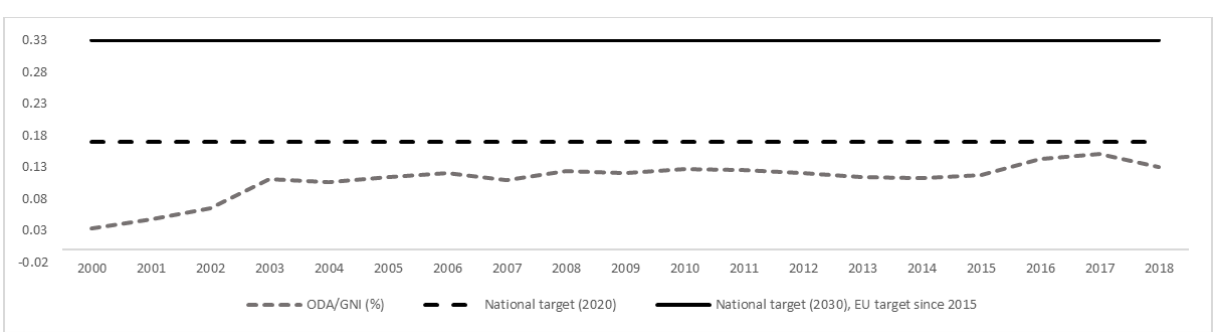

Source: OECD (2020c), own data processing

With respect to internationalcommitments, the Czech Republic should spend on ODA at least $0.70 \%$ of its GNI. The Czech Republic as the EU member state is also committed to the EU commitments concerning the volume of ODA, which were defined for EU-13 members as to spend on ODA at least $0.17 \%$ of GNI by the year 2010 , resp. $0.33 \%$ by the year 2015, when the second target was extended to the year 2030. These targets were proposed to be the national targets by the Czech Republic. The former one should be met by the year 2020 and the latter one by the year 2030 .

The Czech Republic is a ware of its ina dequate aid allocation, but any strategic documents, introduced above, did not show any serious plan how to increase the volume of ODA to meet the targets the Czech Republic is committed to. DAC OECD Special Review (2007) recommended Czech officials to prepare a plan and a timetable to reach the European interim target declared for those EU-13 members (to reach the ratio $0.17 \%$ ODA/GNI by the year 2010), but it was not followed by any strategic political action. A similar recommendation was re-affirmed in the next Peer Review in 2016, when DAC recommended the Czech Republic to have a more ambitious plan how to reach the ratio $0.33 \%$ ODA/GNI (OECD, 2016), which was also re-committed by the Czech Republic itself at the Addis Ababa Conference in 2015.

However, also all DAC members did not meet the international target collectively to spend on ODA at least $0.70 \%$ of their GNI. On avera ge, their ODA flows accounted for $0.28 \%$ of their GNI during the period 2000-2018. International and European targets were 
also not met by four other DAC members selected for the comparison with the Czech Republic. See Figure 2.

Figure 2. Comparison of the volume of ODA flows as s share on GNI (in percent)

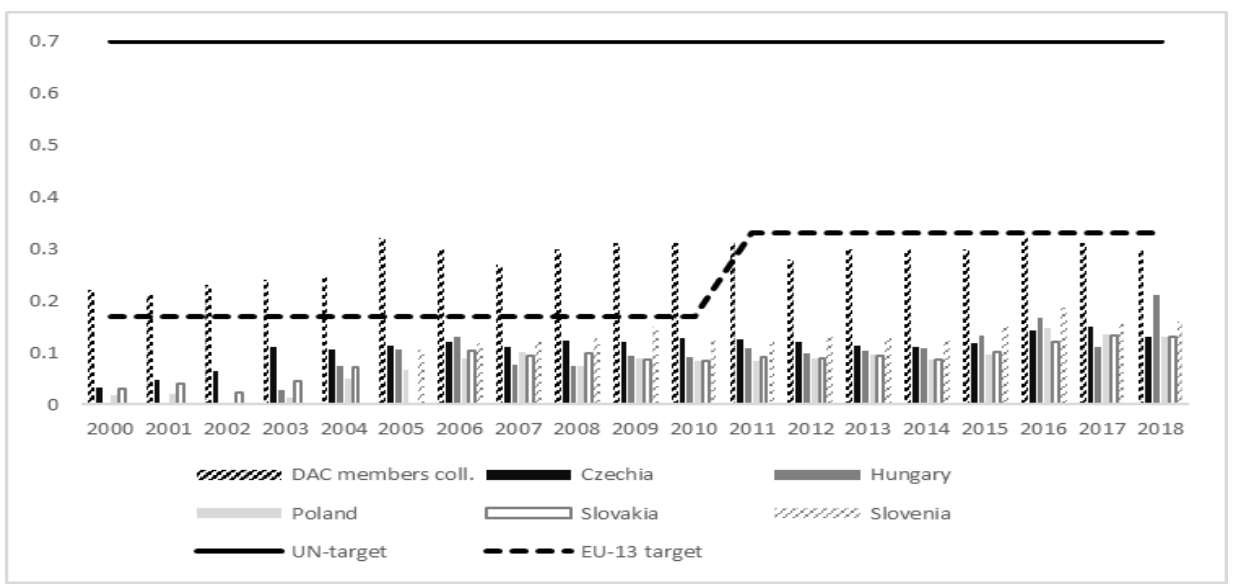

Source: OECD (2020c), own data processing

During the period 2000-2018, the Czech Republic spent on ODA on average $0.11 \%$ of its GNI, which was a similar percentage to Hungary. The lowest average percentage of ODA was allocated by Poland $(0.08 \%)$, whereas the highest one was spent by Slovenia $(0.14 \%)$. Slovenia had the highest ODA/GNI ratio for the period 2007-2017, but Hungary reached the overall highest ODA/GNI ratio, when all five countries and years are considered, in the year $2018(0.21 \%)$. However, the OECD data were available for all analysed countries only for the years 2005-2018. Any of these five countries met neither the DAC members collective ratio, nor the EU commitments defined for EU-13. These findings mean rejection of the second research hypothesis.

In absolute values, the largest volumes of net ODA have been reported for Poland since the year 2004. Polish ODA grew from 51.04 mil. USD to $759.18 \mathrm{mil}$. USD between the years 2000-2018. See Figure 3.

Figure 3. Comparison of the total volume of the net ODA flows (in mil. USD)

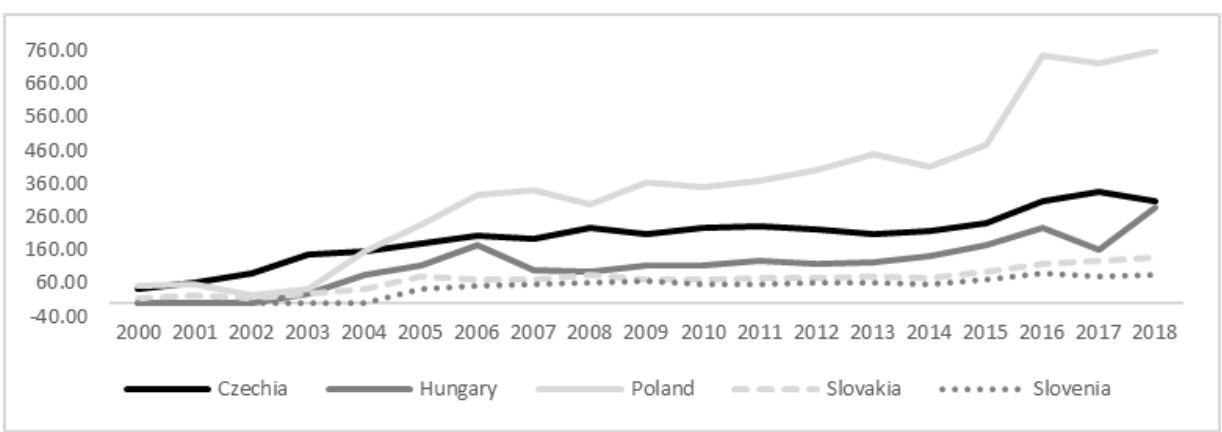

Source: OECD (2020c), own data processing 
Figure 4 shows the year-over-yearabsolute changes in the volumes of totalODA spending. The increase of Czech ODA between the years 2002-2004 was connected not only with the adoption of the first concept of development cooperation, but also with the EU accession. Since the accession to the EU, the Czech Republic has had to contribute to the EU development budget. A similar increase of the ODA flows is visible also for four other countries between the years 2003-2004, when Polish and Slovakian net ODA flows declined between years 2001-2002. The growth of the Polish ODA flows was the most significant between the years 2003-2004, they were increased by 115.9 mil. USD. In the next years, Czech ODA flows were unstable, and even decreased between years 20062007 (by 7 mil. USD), 2008-2009 (by 18.3 mil. USD) and between years 2011-2013 (in sum by more than 21 mil. USD). Drop in ODA flows was also recorded in 2018, when the ODA flows decreased by 30.2 mil. USD. The average growth coefficient of Czech ODA flows accounted for 1.12 and stayed behind those ones calculated for the DAC members' collective ODA flows and for ODA flows of three other selected countries (Hungary 1.13; Poland 1.16; Slovakia 1.13; Slovenia 1.04).

Figure 4. Year-over-year absolute changes in the volumes of ODA flows (in mil. USD)

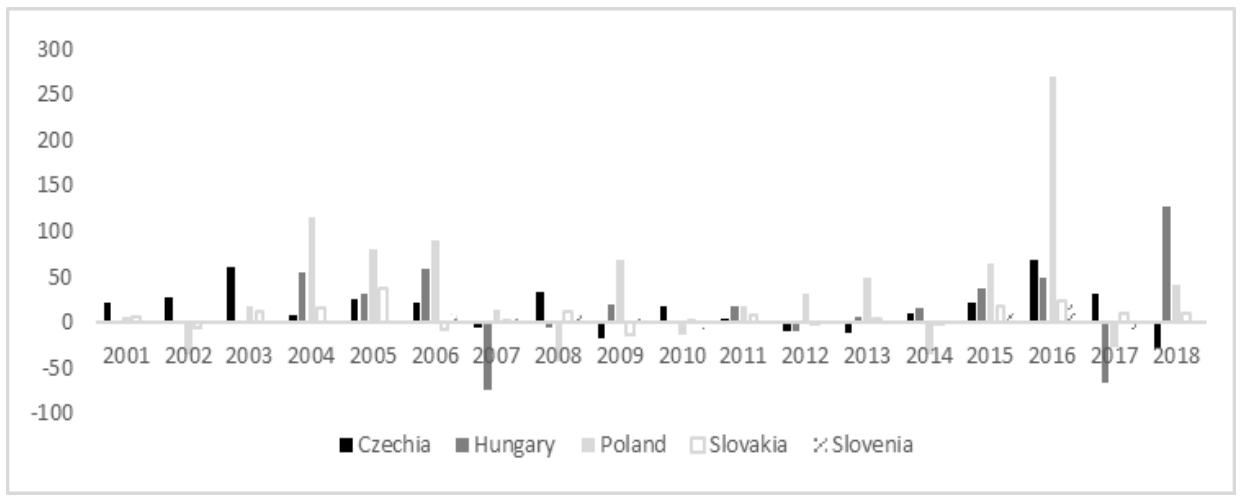

Source: OECD (2020c), own data processing

The OECD indicated that the Czech Republic planed incrementally to increase its ODA flows by 8 mil. USD every year in order to meet its own national target defined as the $0.17 \%$ of GNI on ODA by the year 2020. Since the year 2007 (when the first special peer review was presented), the average annual change of ODA in absolute terms accounted for 10.15 mil. USD. The highest increase was recorded between the years 2016-2017, when the ODA flows grew by $28.37 \%$ (67.30 mil. USD). With respect to nationalplans, introduced in the Development Cooperation Strategy for the years 2010-2017, the Czech Republic should have increased its ODA/GNI ratio by 0.01 p.p. since 2010 . If the plan was met, the ODA/GNI would have accounted for $0.20 \%$ in 2017 . However, ODA flows accounted for only $0.15 \%$ of GNI. In 2017 , the FoRS pointed out that the Czech Republic needed a concrete and binding medium-term plan for the systematic and predictable growth of the ODA/GNI ratio to meet the national target $(0.33 \%$ ODA/GNI) by the year 2030. 


\section{Volume and territorial distribution of ODA flows allocated to LDCs}

The first Concept of Foreign Development Aid for the period 2002-2007 recognized six priority regions with twenty priority partner countries for the development cooperation, including six LDCs (Afghanistan, Angola, Burkina Faso, Ethiopia, Mali and Yemen). However, in 2004, the number of partner countries was reduced to eight countries, including only three LDCs. The Concept also specified several conditions that had to be met for the selection of priority partner countries, when the level of development was only one precondition. Representation of LDCs among priority countries was evaluated as important in the Concept, when the document stated necessity to increa se the allocation of ODA to these countries (Czech Republic, Ministry of Foreign Affairs, 2001) to reach the OECD members a vera ge percenta ge share of ODA allocations to LDCs on total ODA spending (25\% in 2001). The DAC Special Peer Review did not show positive results when the allocation of ODA to LDCs was evaluated because the Czech Republic allocated to LDCs only 7 mil. USD of bilateral ODA flows between the years 2004 and 2005. With respect to countries classification, the majority of the Czech ODA recipients had the status of lower-middle-income countries, when the LDCs and other low-income countries received only $7.3 \%$ of the Czech bilateralODA flows in 2004, resp. 12.5\% in 2005 (OECD, 2007). The proportion of the net ODA flows (including bilateral and multilateral flows) to LDCs on totalODA flows did not exceed $10 \%$ during the Concept time framework and even declined significantly in 2005. See Figure 5.

Figure 5. Czech ODA flows to LDCs as a percentage of total ODA flows

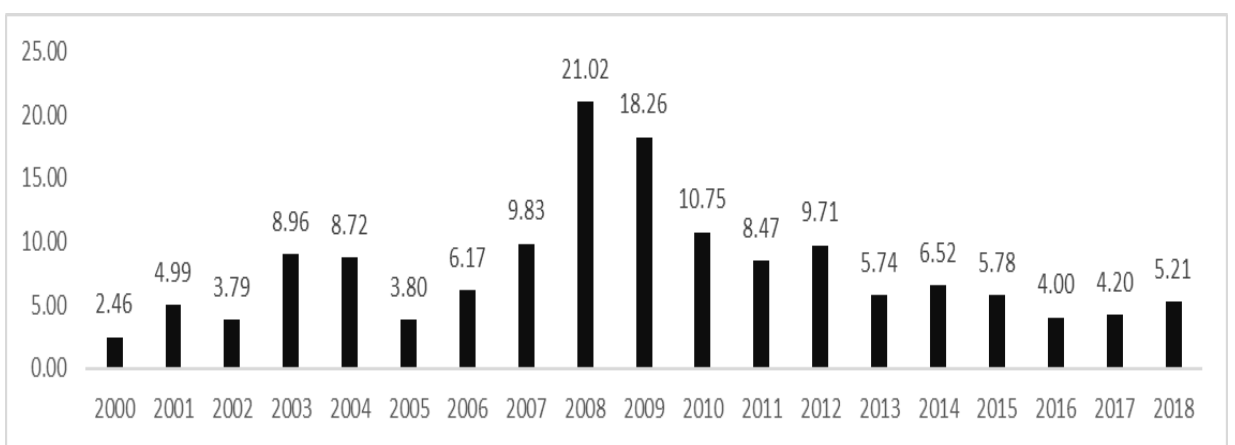

Source: OECD (2020c), own data processing

The Development Cooperation Strategy of the Czech Republic, adopted for the years 2010-2017, introduced four criteria for the selection of territorial priorities, when the emergency of the aid (with respect to countries' socio-economic development) was stated as the second criterium. Based on differing forms of cooperation, fourteen countries were indicated among the Strategy's territorial priorities when six LDCs were included there (Afghanistan, Angola, Ethiopia, Cambodia and Zambia). The second DAC OECD Peer Review showed significant progress when the bilateral ODA flows to LDCs reached 26\% of the total bilateral ODA flows in 2013, resp. 27\% in 2014 (OECD, 2016). The proportion of the net ODA flows to LDCs on totalODA flows (including bilateral and multilateral flows) started to decline significantly before the year when the Strategy came into force (in 2009). By the end of the year 2017, they did not meet their volume of the year 
2010 (24.14 mil. USD), and thus the proportion of ODA flows to LDCs in total ODA flows significantly declined too. See Figure 5 above.

The last Development Cooperation Strategy 2018-2030 states priority partner countries in relation to government statements introduced in 2016, and specifies them only in footnotes added to the main text of the Strategy. Currently, the Czech Republic has six priority countries, including three LDCs (Ethiopia, Cambodia and Zambia), when another LDC is included among specific countries (Afghanistan). Political declarations thus got priorities to middle-income countries and LDCs in a balanced way, but the financiala llocation remained unbalanced. In 2018, only $5.21 \%$ of the total net Czech ODA was allocated to LDCs, which was lower by 2 p.p. than the avera ge share calculated for the period 2000 2018. The proportion of the ODA flows to LDCs in totalODA flows between the years 2000 and 2018 are presented above in Figure 5. With respect to political declarations, it seems that the Czech Republic tries to reduce the number of priority countries and thus to lower the fragmentation of ODA spending.

Figure 6 shows the relation between the Czech ODA flows to LDCs and totalODA flows. Each point is defined by the volume of total net ODA flows and these ODA flows allocated to LDCs in a certain year. The points' position shows that in some years, total volume of ODA flows increased, while the ODA flows to LDCs rather stagnated (years 2000-2005; 2016-2017). In some years, total ODA flows increa sed or decreased slightly, while ODA flows to LDCs decreased rapidly (2009-2010). Since 2009, the allocation of ODA to LDCs did not exceed the volume reported for the year 2008 (47.54 mil. USD), and have declined. In recent years, the lowest allocation was reported for the year 2013 (11.9 mil. USD). It means that an increase in total net ODA flows is not accompanied by the increase in ODA allocation to LDCs. It seems that despite the political declarations, LDCs stay beyond the main scope of the Czech development cooperation.

Figure 6. Relation between total Czech ODA flows and ODA flows to LDCs (volumes in mil. USD)

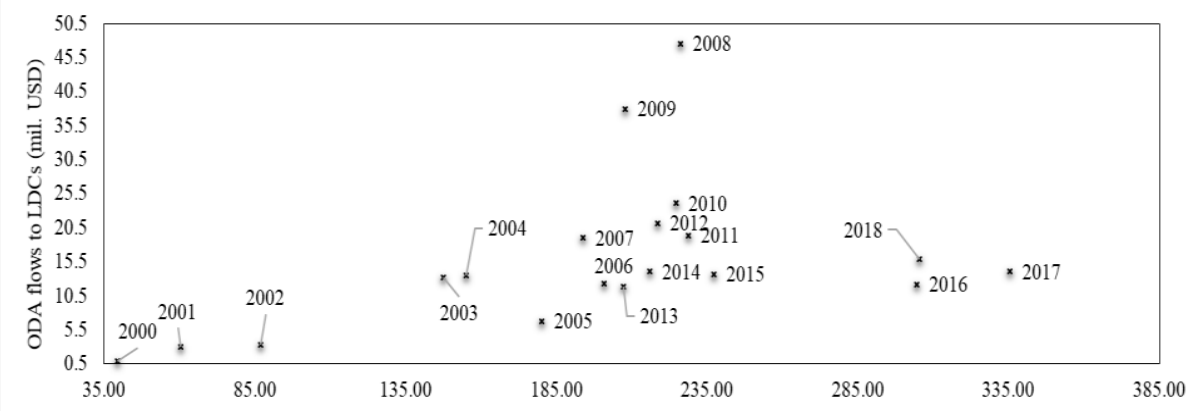

Total ODA flows (mil. USD)

Source: OECD (2020c), own data processing 
However, an international target concerning the volume of ODA allocation to LDCs (defined as to spend on ODA for LDCs $0.15-0.20 \%$ of GNI) is not met too, when the collective ODA flows of all DAC members are examined. On average, during the period 2000 2018 , DAC members allocated $19.23 \%$ of their ODA to LDCs. If they spent on ODA on a vera ge $0.28 \%$ of their GNI during the same period, they allocated to LDCs about $0,05 \%$ of their GNI. This marginal percentage corresponds to the fact that the majority of DAC members identified their priority partner countries among middle-income countries. Comparison of the Czech ODA flows to LDCs with four other selected DAC members is presented in Figure 7.

Low allocation of ODA flows to LDCs is a gain related to strategic territorial priorities of the Czech Republic and four other countries. The Czech Republic focuses especially on the cooperation with the Eastern European countries and Western Balkans countries. It would like to share its own experience with political and economic transformation with transforming countries in both regions. Hungary, Poland, Slovakia and Slovenia have got the same aspiration.

Figure 7. Comparison of the ODA flows to LDCs as a percentage of total ODA flows

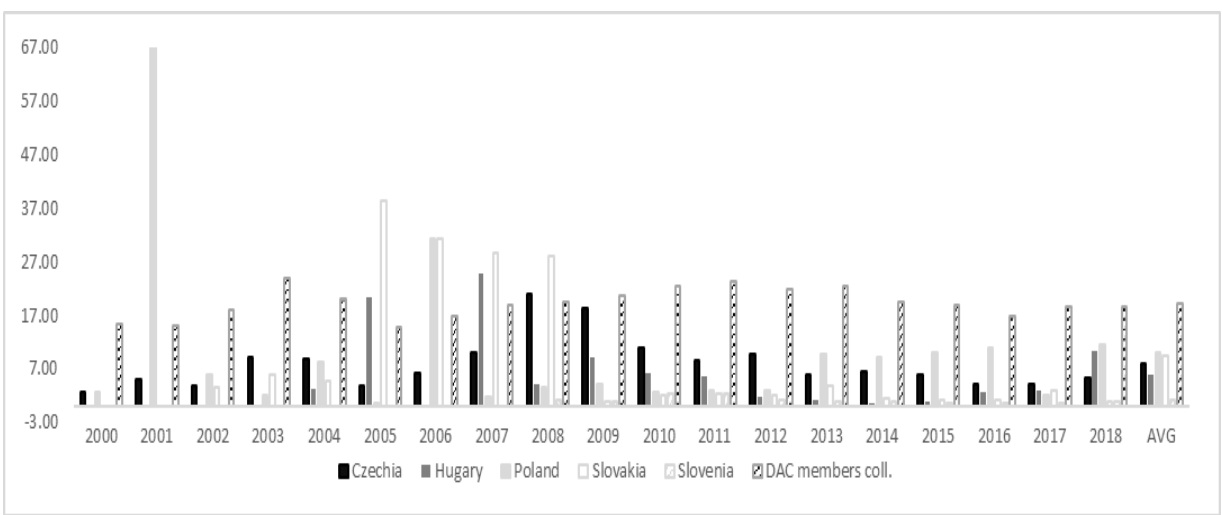

Source: OECD (2020c), own data processing

Czech Republic, Hungary, Poland, Slovakia and Slovenia do not find their key partner countries among the LDCs when the volumes of ODA allocation is considered, but some LDCs are recognized as the priority partners in countries' strategic documents framing their development cooperation. See the comparison of priority partner countries in Table 1. The term priority country is assigned to all countries mentioned in strategic documents as countries on which some form of development cooperation will be focused. 
Table 1. LCDs' representation in priority countries' lists: Czech Republic versus four selected DAC members

\begin{tabular}{|c|c|c|c|}
\hline Country & $\begin{array}{l}\text { Act in } \\
\text { force } \\
\text { since }\end{array}$ & $\begin{array}{c}\text { Current Strategy } \\
\text { Priority countries } \\
\text { (LDCs included in the list) }\end{array}$ & $\begin{array}{c}\text { Former Strategy } \\
\text { Priority countries } \\
\text { (LDCs included in the list) }\end{array}$ \\
\hline $\begin{array}{l}\text { Czech Re- } \\
\text { public }\end{array}$ & 2010 & $\begin{array}{l}\text { Development Cooperation Strategy 2018- } \\
2030 \\
6 \text { priority countries (Ethiopia, Cambodia and } \\
\text { Zambia) }\end{array}$ & $\begin{array}{l}\text { The Development Cooperation Strategy, } \\
\text { adopted for the years 2010-2017 } \\
14 \text { priority countries (Afghanistan, Angola, } \\
\text { Ethiopia, Cambodiaand Zambia) }\end{array}$ \\
\hline Poland & 2011 & $\begin{array}{l}\text { Multiannual Development cooperation } \\
\text { Programme 2016-2020 } \\
12 \text { priority countries (Ethiopia, Myanmar, } \\
\text { Senegal, Tanzania, Uganda) }\end{array}$ & $\begin{array}{l}\text { Multiannual Programme of Development } \\
\text { cooperation for 2012-2015 } \\
20 \text { priority countries (Burundi, Ethiopia, } \\
\text { Rwanda, Somalia, South Sudan, Tanzania, } \\
\text { Uganda, Afghanistan) }\end{array}$ \\
\hline Hungary & 2014 & $\begin{array}{l}\text { International Development cooperation } \\
\text { Strategy and Strategic Concept for Inter- } \\
\text { national Humanitarian Aid of Hungary } \\
2014-2020 \\
\text { No priority countries are specified/only prior- } \\
\text { ity regions are specified }\end{array}$ & 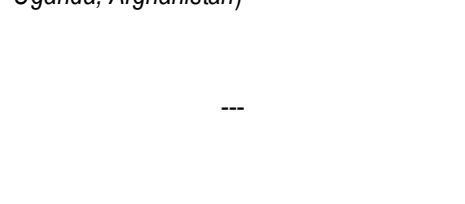 \\
\hline Slovakia & 2015 & $\begin{array}{l}\text { Medium-term Strategy for Development } \\
\text { cooperation of the Slovak Republic for } \\
2019-2023 \\
27 \text { priority countries (Afghanistan, Bu- } \\
\text { rundi, Eritrea, Ethiopia, Rwanda, Somalia, } \\
\text { South Sudan, Tanzania, Uganda) }\end{array}$ & $\begin{array}{l}\text { Medium-term Strategy for Development } \\
\text { cooperation of the Slovak Republic for } \\
\text { 2014-2018 } \\
10 \text { priority countries (Afghanistan, South Su- } \\
\text { dan) }\end{array}$ \\
\hline Slovenia & 2018 & $\begin{array}{l}\text { Development Cooperation and Humani- } \\
\text { tarian Aid Strategy of the Republic of Slo- } \\
\text { venia until } 2030 \\
\text { No priority countries are specified, only pri- } \\
\text { ority regions are specified (in case of Africa, } \\
\text { priority is assignedto LDCs) }\end{array}$ & $\begin{array}{l}\text { Framework Programme of the Interna- } \\
\text { tional Development Cooperation and Hu- } \\
\text { manitarian aid of the Republic of Slove- } \\
\text { nia for the Period from } 2016 \text { to } 2019 \text { (up- } \\
\text { dated twice time) } \\
13 \text { priority countries (Afghanistan, Cabo } \\
\text { Verde) }\end{array}$ \\
\hline
\end{tabular}

Sources: Czech Republic, Ministry of Foreign Affairs (2017, 2010); Hungary, Ministry of Foreign Affairs and Trade (2020a, b); Slovenia, Ministry of Foreign Affairs (2020a, b); SlovakAid (2020a, b); Website of the Republic Poland gov.pl (2020a, b), own data processing.

The territorial distribution of ODA flows can be examined using the updated HerfindahlHirschman Market Concentration Index (HHI) introduced by the World Bank (2013), when the ODA flows are used instead of trade flows. HHI is defined above with the Equation (1). The range of the HHI values is defined from 0 to 1 . A higher value indicates that flows are concentrated in a few countries. Some analyses (Sládková, 2011; Dostál, Jermanová, 2017) show that Czech development cooperation suffers from long-term systematic problems, especially territorial and sectoral fragmentation. Also, both OECD peer reviews recommended to the Czech Republic to reduce the number of priority partner countries. Therefore, as the optimal results should be considered, values of HHI close to 1. See the Values of HHI in Figure 8 and Appendix 1. 
Figure 8. HHI values for the Czech Republic and four other countries during the period of years 2000-2008

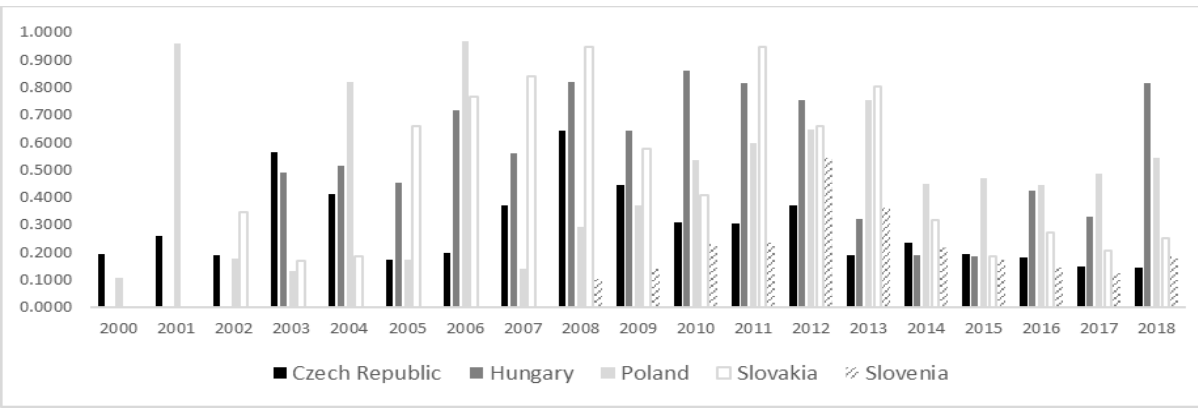

Source: OECD (2020d), own data processing

Besides the years 2000 and 2003, on average, the Czech Republic ha d more fragmented ODA flows to LDCs than four other countries in the same years. The highest value of HHI (0.6414) was achieved by the Czech Republic in 2008, but it was not the highest value in comparison with other countries' results in other years. Results of this year and four following years were impacted with quite high allocation of the ODA flows to Afghanistan, which accounted for $80 \%$ of total ODA flows to LDCs (the year 2008), respectively from $53 \%$ to $66 \%$ in the following years. This finding means rejection of the fourth research hypothesis.

The top 10 LDCs, where the highest volume of Czech ODA flows was allocated for the period 2000-2018, are presented in Table 2.

Table 2. Top 10 LDCs with the highest volume of Czech ODA flows - total flows for the years 2000-2018

\begin{tabular}{lcc} 
Country & ODA flows (mil. USD) & $\begin{array}{c}\text { ODA flows } \\
\text { (\% of total allocation to LCDs) }\end{array}$ \\
\hline Afghanistan & 162.29 & 53.25 \\
Ethiopia & 37.51 & 12.31 \\
Zambia & 15.19 & $4 ., 98$ \\
Cambodia & 14.47 & 4.75 \\
Angola & 11.94 & 3.92 \\
Yemen & 11.69 & 3.84 \\
Myanmar & 11.64 & 3.82 \\
Mali & 5.41 & 1.78 \\
Congo, Dem. Rep. & 3.57 & 1.17 \\
Haiti & 3.45 & 1.13 \\
\hline
\end{tabular}

Source: OECD (2020d), own data processing

The top 10 countries presented above accounted for $91 \%$ of all Czech ODA flows allocated to LDCs in the period 2000-2018. On the other hand, ODA of less than 1 mil. USD was allocated to $26 \mathrm{LDCs}$, and no ODA flows were reported only for three countries Kiribati, EquatorialGuinea (graduating from the LDC status in 2017), and Samoa (graduating from the LDC status in 2014). Comparison of the top 5 countries for all five donor countries is presented in Table 3, which also shows the number of LDCs with no ODA flows and ODA allocation to the top 10 countries for the Czech Republic and fourother countries. 
Table 3. Allocation of ODA flows to top 5 LDCs - total flows for the years 2000-2018

\begin{tabular}{lllll} 
Czech Republic & Hungary & Poland & Slovakia & Slovenia \\
$\mathbf{2 0 0 0 - 2 0 1 8}$ & $\mathbf{2 0 0 3 - 2 0 1 8}$ & $\mathbf{2 0 0 0 - 2 0 1 8}$ & $\mathbf{2 0 0 2 - 2 0 1 8}$ & $\mathbf{2 0 0 8 - 2 0 1 8}$ \\
\hline Afghanistan & Afghanistan & Angola & Sudan & Afghanistan \\
$53.25 \%$ & $29.98 \%$ & $34.06 \%$ & $55.83 \%$ & $35.77 \%$ \\
Ethiopia & Lao, Pep. Dem. R. & Ethiopia & Liberia & Chad \\
$37.5 \%$ & $13.75 \%$ & $22.87 \%$ & $19.79 \%$ & $13.95 \%$ \\
Zambia & Mozambique & Tanzania & Afghanistan & Burundi \\
$15.19 \%$ & $13.75 \%$ & $11.78 \%$ & $15.70 \%$ & $8.43 \%$ \\
Cambodia & Yemen & Myanmar & South Sudan & Rwanda \\
$14.47 \%$ & $11.38 \%$ & $11.63 \%$ & $2.28 \%$ & $7.87 \%$ \\
Angola & Tanzania & Afghanistan & Mozambique & Congo, Dem. Rep. \\
$11.94 \%$ & $8.91 \%$ & $7.80 \%$ & $1.20 \%$ & $4.14 \%$ \\
Top 10 & Top 10 & Top 10 & Top 10 & Top 10 \\
$90.95 \%$ & $98.45 \%$ & $97.43 \%$ & $98.65 \%$ & $83.56 \%$ \\
No flows & Now flows & Now flows & Now flows & No flows \\
3 LDCs & 25 LDCs & 10 LDCs & 24 LDCs & 25 LDCs \\
\hline
\end{tabular}

Source: OECD (2020d), own data processing

Findings presented in Table 3 confirm that the Czech Republic had higher fragmentation of ODA flows allocated to LDCs than Hungary, Poland and Slovakia, which means rejection of the fifth research hypothesis. Results also show clearly that Afghanistan belongs to countries with the highest priority when all five countries allocated a significant part of their ODA volumes there during the analysed periods of years. Czech Development Cooperation Strategy for the years 2018-2030 introduces only six priority partner countries for bilateral development cooperation, and each country cooperation is expected to be focused on fewer thematic priorities (maximum is defined as three priorities). Therefore, development cooperation is under the conditions of the current Strategy designed to meet the recommendation of the DAC OECD to increase the impact of the Czech development cooperation (Czech Republic, Ministry of Foreign Affairs, 2017).

\section{Discussion and conclusion}

Although the Czech Republic as a member of the Development Assistance Committee of the OECD and a member of the European Union, belongs to the most important donors of the foreign development aid, the above-presented results showed that it is far from meeting these interactionally declared commitments.

The Czech Republic introduced the first principles of its foreign development cooperation as the first post-communist European country in the mid-1990s. Since then, significant progress has been made when the specification of priorities, principles and cooperation forms are considered, which is reflected in both strategic documents framing Czech development policy during the period 2002-2017, and also in the latest Strategy for the years 2018-2030. However, no significant progress was made when the fulfilment of international, EU and national targets defined for the volume of ODA are considered. With respect to them, the Czech Republic should spend on ODA at least $0.33 \%$ of its GNI (the EU and Czech national target), resp. $0.70 \%$ of its GNI (the United Nations target). Also, the allocation of ODA to the Least Developed Countries is not adequate and does not meet the target volumes $(0.15-0.20 \%$ of GNI). 
Therefore, it can be claimed that:

(1) The Czech Republic made only a little progress in meeting the national, EU and international targets concerning the volume of $O D A$, which means rejection of the first research hypothesis.

The volume of the Czech ODA flows in the percentage of GNI was quite stable during the period 2003-2015 and oscillated a round 0.11\%. In 2010, the Czech Republic declared to increase this ratio by 0.01 p.p. every year. If this plan was met, the ratio should have accounted for $0.20 \%$ in 2017 . However, it reached the level of $0.14 \%$ in 2016, resp. $0.15 \%$ in 2017 . For the year 2018 , a decline to $0.13 \%$ is reported. And what is more important, no development cooperation strategy introduced a serious plan on how to increase the volume of ODA to meet the targets the Czech Republic is committed to.

(2) The Czech Republic did not spend on ODA a higher percentage of its GNI than four othercountries, which means rejection of the second research hypothesis.

OECD data about the volume of ODA as a percentage of GNI are a vailable for all analysed countries (Czech Republic, Hungary, Poland, Slovakia, Slovenia, all DAC members collectively) only for the period 2005-2018. During this period, the Czech Republic did not have the highest ODA/GNI ratio, the highest values were reached by all DAC members collectively, followed by Slovenia. In 2005, 2010 and 2011, the Czech ratio was comparable to the Slovenian one, in the rest of the time period, it was lower by 0.01 to 0.05 p.p.

(3) The LDCs belonged to priority partner countries defined with strategic documents framing the Czech development cooperation, which means acceptation of the third research hypothesis.

Strategic documents, specifying thematic and territorial priorities of the Czech development cooperation during the period 2002-2018, introduced some Least Developed Countries as the priority partner countries, and they were represented in a balanced way in comparison with other priority partner countries: (1) Concept for the years 2002-2007 recognized 20 priority countries including 6 LDCs (later number of the priority countries was reduced to 8, including 3 LDCs); (2) Strategy for the years 2010-2017 recognized 14 priority countries, including 6 LDCs; (3) Strategy for the years 2018-2030 recognized 6 priority countries, including 3 LDCs (as a specific country was recognized another LDC - Afghanistan). However, allocation of the ODA flows to LDCs was inadequate in relation to this representation. The Czech Republic allocated to LDCs from $2.46 \%$ to $21.02 \%$ of its total ODA flows, but the level of $10 \%$ was exceeded only in three years: 2008 (21.02\%), 2009 (18.26\%) and $2010(10.75 \%)$. On avera ge, the Czech Republic allocated to LDCs about $8 \%$ of its totalODA flows for the years 2000-2018. In absolute terms, the ODA allocation to LDCs accounted totally for 304.43 mil. USD during the period 2000 2018.

(4) The Czech Republic did not follow the recommendations to lower the level of the ODA flows fragmentation, which means rejection of the fourth research hypothesis.

When the fragmentation of ODA flows to LDCs is considered and was evaluated using the updated Herfindahl-Hirschman Market Concentration Index, no significant progress towards the lower fragmentation was observed. Higher values of HHI (it means lower 
fragmentation) in some years were connected only with the higher ODA flows to Afghanistan. The Czech Republic tried to reduce the number priority countries in its strategic documents framing the thematic and territorial priorities of Czech development cooperation, but it is not visible in the increase of HHI, and thus real lowering of ODA flows fragmentation.

(5) The level of fragmentation of the Czech ODA flows to LDCs was higher than the level offour other countries, which means rejection of the fifth research hypothesis.

During the years 2008-2018, the fragmentation of Czech ODA flows to LDCs was higher than those ones observed for the Hungarian, Polish or Slovakian ODA flows to LDCs. Also, other variables followed - number of LDCs with no ODA inflows and share of top 10 countries (receiving the highest volumes of ODA inflows from the a nalysed countries) on totalODA flows to LDCs indicated higher territorial fragmentation Czech ODA flows.

The above presented findings reveal clearly that Czech political authorities should commit themselves to increase spending on ODA to meet the Czech nationaland EU targets concerning the volume of ODA. Steps towards lower fragmentation should be taken too, and some have already been introduced (lowering the number of priority partner countries). Findings also correspond to the fact that the Czech foreign development cooperation is considered a part of the whole foreign policy of the Czech Republic too. Therefore, priority partnercountries are chosen not only with respect to their underdevelopment and externalfinancing needs, and thus the emergency of aid, but also with respect to political and pragmatic purposes. Therefore, major partner countries have the status of middleincome countries, when the priority partner countries are recognized in Eastern Europe or Western Balkans. On the other hand, if the Act on Development Cooperation and Humanitarian Aid considers the main aim of the development cooperation eradication of poverty in the context of sustainable development, then the priority has to be assigned to countries with the objective lack of financial resources for the gross fixed capital formation that can contribute to the sustainable development and to the poverty reduction there. However, this priority is rather a political declaration not followed by real political effort because Czech ODA allocation to LDCs is marginal with respect to total ODA flows. Despite above-presented findings, it is necessary to add that the Czech Republic behaves like many other OECD Development Assistance Committee members and no significant differences were found in comparison with Hungary, Poland, Slovakia and Slovenia.

Conflict of Interest: No potentialconflict of interest was reported by the author.

\section{References}

COLliER, P., DOLlAR, D. (2002). Aid Allocation and Poverty Reduction. European Economic Review. 46(8), p. 1475-1500. DOI: 10.1016/S0014-2921(01)00187-8

CHENERY, H. B. (1967). Foreign Assistance and Economic Development. In: ADLER J. H. (ed.). Capital Movements and Economic Development. InternationalEconomic Association Conference Volumes. London: Palgrave Macmillan. 
CZECH REPUBLIC. MINISTRY OF FOREIGN AFFAIRS (2017). Development Cooperation Strategy of the Czech Republic 2018-2030 [online]. Retrieved 2020-07-15 from https://www.mzv.cz/file/2710363/CZ_Development_Cooperation_Strategy_2018_2030.pdf.

CZECH REPUBLIC. MINISTRY OF FOREIGN AFFAIRS (2010). Strategy of the Development Cooperation of the Czech Republic 2010-2017 [online]. Retrieved 2020-07-28 from http://www.czechaid.cz/wp-content/uploads/2016/09/Development_Cooperation_Strategy_2010_2017.pdf.

CZECH REPUBLIC (2010). Act of 21 April 2010 on Development Cooperation and Humanitarian Aid, and Amending Related Laws [online]. Retrieved 2020-07-24 from https://www.mzv.cz/public/51/66/1/541617_437009_Act_on_Development_Cooperation.pdf.

CZECH REPUBLIC. MINISTRY OF FOREIGN AFFAIRS (2001). Concept of Foreign Development Aid of the Czech Republic for the period of years 2002 -2007 [online]. Retrieved 2020-07-28 from https://www.mzv.cz/public/7/36/4a/18290_14945_zrp_cz.pdf, last accessed 2020/07/28.

FORS. ČESKÉ FÓRUM PRO ROZVOJOVOU SPOLUPRÁCI (2017). Aid Watch 2017. Praha: České fórum pro rozvojovou spolupráci.

DOSTÁL, V. JERMANOVÁ, T. eds. (2017). Agenda pro českou zahraniční politiku 2017. Praha: Asociace pro meziná rodní otázky.

EASTERLY, W. (2007). Was Development Assistance a Mistake? The American Economic Review. 97(2), p. 328-332.

EUROPEAN UNION (2018). EU remains the world's leading donor of development assistance: $€ 75.7$ billion in 2017 [online]. Retrieved 2020-11-28 from https://ec.europa.eu/commission/presscorner/detail/en/IP_18_3002.

EUROPEAN UNION (2017). The New European Consensus on Development [online]. Retrieved 2020-07-28 from https://ec.europa.eu/international-partnerships/system/files/european-consensus-on-development-final-20170626_en.pdf.

GORE, Ch. (2003). Globalization, the International Poverty Trap and Chronic Poverty in the Least Developed Countries. Chronic Poverty Research Centre Working Paper No. 30, p. 1-12. DOI: http://dx.doi.org/10.2139/ssrn.1754435.

HARMÁČEK, J., SYROVÁTKA, M., OPRŠAL, Z. (2017). Analýza faktorů selekce a a lokace české rozvojové pomocis využitím panelových dat a metod Probit a Tobit. Politická ekonomie. 65(2), p. 179-197.https://doi.org/10.18267/j.polek.1135.

HORKÝ, O. (2011). Depoliticization, instrumentalization and legitimacy of Czech development cooperation: A case of imposed altruism? Éthique et économique/Ethics and Economics. 8(1), 120-132.

HUNGARY. MINISTRY OF FOREIGN AFFAIRS AND TRADE (2020a). International Development Cooperation Strategy and Strategic Concept for International Humanitarian Aid of Hungary 2014-2020 [online]. Retrieved 2020-08-25 from: https://nefe.kormany.hu/download/3/93/c0000/International\%20Development\%20Cooperation\%20and $\% 20$ Humanitarian\%20Aid $\% 20$ Stra tegy $\% 20$ of\%20Hungaryv\%C3\%A9gleges.pdf. 
HUNGARY. MINISTRY OF FOREIGN AFFAIRS AND TRADE (2020b). Hungarian Legislation on International Development Cooperation [online]. Retrieved 2020-08-25 from: https://nefe.kormany.hu/hungarian-legislation-on-international-development-cooperation.

IZEVBIGIE, J., ISIKHUEMEN, H., OGBEIFUN, M. (2020). Foreign Aid Inflows and Economic Growth in ECOWAS Sub-Region. Journal of Academic Research in Economics. 1, p. 108-121.

KRYLOVÁ, P., SYROVÁTKA, M. OPRŠAL, Z. (2012) Assessing the Aid effectiveness of the Czech Republic: Commitment to Development Index and Beyond. Perspectives on European Politics and Society. 13(1), p. 100-116. DOI: 10.1080/15705854.2011.649170 MALLIK, Girijasankar (2008). Foreign Aid and Economic Growth: A Cointegration Analysis of the Six Poorest African Countries. Economic Analysis and Policy. 38(2), p. 251-260. DOI: 10.1016/S0313-5926(08)50020-8.

MOSLEY, P., HUDSON, J. VERSCHOOR, A. (2004). Aid, Poverty Reduction and the "New Conditionality". The Economic Journal. 114(496), p. F2017-F243. DOI: 10.1111/j.1468-0297.2004.00220.x

MOYO, D., MYERS, J. J. Why Aid Is Not Working and How There Is a Better Way for Africa [online], Transcript of Dambisa Moyo's interview with Joanne J. Myers, 2 April 2009. Carnegie Council for Ethics in International, Affairs. Retrieved 2020-01-12 from https://www.researchgate.net/publication/38091995_Dead_aid_Why_aid_is_not_working_and_how_there_is_a_better_way_for_Africa .

ORGANISATION FOR ECONOMIC CO-OPERATION AND DEVELOPMENT (2020a). Official Development Assistance [online]. Retrieved 2020-07-25 from http://www.oecd.org/dac/financing-sustainable-development/development-financestandards/What-is-ODA.pdf.

ORGANISATION FOR ECONOMIC CO-OPERATION AND DEVELOPMENT (2020b). Modernisation of the DAC statistical system [online]. Retrieved 2020-11-28 from http://www.oecd.org/dac/financing-sustainable-development/modernisation-dacstatistical-system.htm.

ORGANISATION FOR ECONOMIC CO-OPERATION AND DEVELOPMENT (2020c). Net ODA (indicator) [online]. Retrieved 2020-07-25 from: https://data.oecd.org/oda/net-oda.htm. doi: 10.1787/33346549-en.

ORGANISATION FOR ECONOMIC CO-OPERATION AND DEVELOPMENT (2020d). Total official development flows by country and region [online]. Retrieved 2020 08-15 from_https://stats.oecd.org/.

ORGANISATION FOR ECONOMIC CO-OPERATION AND DEVELOPMENT (2016). OECD Development Co-operation Peer Reviews: Czech Republic 2016. Paris: OECD Publishing, http://dx.doi.org/10.1787/9789264264939-en.

ORGANISATION FOR ECONOMIC CO-OPERATION AND DEVELOPMENT (2007). OECD DAC Special Review of the Czech Republic's Development Cooperation 2007 [online]. Retrieved 2020-07-20 from_https://www.oecd.org/dac/dac-global-relations/specialreviewoftheczechrepublicsdevelopmentco-operation2007.htm.

SACHS, J. D. (2012). From MDGs to SDGs. The Lancet, 379(9832), p. 2206-2211. 
SACHS, J. D. (2005). The Development Challenge. Foreign Affairs. 84(2), p. 78-90.

SACHS, J. D., MCARTHUR, J. W. (2005). The Millennium Project: A Plan for Meeting the Millennium Development Goals. Lancet. 365, p. 347-353. DOI: 10.1016/S01406736(05)17791-5

SACHS, J. D. et al. (2004). Ending Africa's Poverty Trap. Brookings Papers on Economic Activity. 1, p. 117-240.

SLÁDKOVÁ, Z. (2011). Czech Republic and its Official Development Assistance [online]. Association for International Affairs Czech Forum for Development Cooperation Briefing Paper 2/2011. Retrieved 2020-07-20 from http://www.fors.cz/user_files/fors_bf.pdf.

SLOVAKAID (2020a). Medium-term Strategyfor Development cooperation of the Slovak Republic for 2014-2018 [online]. Retrieved 2020-08-20 from https://issuu.com/slovakaid/docs/strednodoba_strategia_oda_sr_2014-2_83963017c1b288.

SLOVAKAID (2020b). Medium-term Strategyfor Development cooperation of the Slovak Republic for 2019-2023 [online]. Retrieved 2020-08-20 from https://www.slovakaid.sk/sites/default/files/strednodoba_strategia_rozvojovej_spoluprace_eng_20192023_644_stran_final.pdf.

SLOVENIA. MINISTRY OF FOREIGN AFFAIRS (2020a). Development Cooperation and Humanitarian Aid Strategy of the Republic of Slovenia until 2030 [online]. Retrieved 2020-08-20 from_https://www.gov.si/assets/ministrstva/MZZ/Dokumenti/multilaterala/razvojno-sodelovanje/Development-Cooperation-and-Humanitarian-Aid-Strategyof-the-Republic-of-Slovenia.pdf.

SLOVENIA. MINISTRY OF FOREIGN AFFAIRS (2020b). Okvirni program mednarodnega razvojnega sodelovanja in humanitarne pomoči Republike Slovenije za obdobje od leta 2016 do 2019 [online]. Retrieved 2020-08-20 from https://www.gov.si/assets/ministrstva/MZZ/Dokumenti/multilaterala/razvojno-sodelovanje/fdcb6f045c/Okvirni-program-MRS-za-obdobje-2016-2019.pdf.

SUPHIAN, R., KIM, S. (2016). ODA and Economic Growth in East African Countries. Journal of Peace Studies. 18(2), p. 143-167.

SYROVÁTKA, M., KRYLOVÁ, P. (2012). Aid Dimension of the commitment to development index: case study of the Czech Republic. International Journal of Sustainable Economy. 4(4), p 323-339. DOI: 10.1504/IJSE.2012.049611.

UNITED NATIONS (2019). Least Developed Countries Report. The presence and future of external development finance - old dependence, new challenge. New York, United Nations.

UNITED NATIONS (2011). Programme of Action for the Least Developed Countries for the Decade 2011-2020 [online]. Retrieved 2020-07-25 from http://unohrlls.org/UserFiles/File/IPoA.pdf.

UNITED NATIONS (2015). Transforming our world: the 2030 Agenda for Sustainable Development [online]. Retrieved 2020-07-25 from https://sustainabledevelopment.un.org/post2015/transformingourworld. 
UNITED NATIONS (2015). Addis Ababa Action Agenda. Financing for Development [online]. Retrieved 2020-07-25 from https://sustainabledevelopment.un.org/content/documents/2051AAAA_Outcome.pdf.

UNITED NATIONS CONFERENCE ON TRADE AND DEVELOPMEN (2020). Least Developed Countries [online]. Retrieved 2020-07-25 from https://unctad.org/en/pages/aldc/least\%20developed\%20countries/ldcs.aspx.

WEBSITE OF THE REPUBLIC OF POLAND (2020a). Polish aid [online]. Retrieved 2020-08-25 from https://www.gov.pl/web/polishaid.

WEBSITE OF THE REPUBLIC OF POLAND (2020b). Multiannual Development Cooperation Programme 2016-2020 [online]. Retrieved 2020-08-25 from https://www.gov.pl/web/polishaid/multiannual-development-cooperation-programme2016-2020.

WORLD BANK (2013). Online Trade Outcomes Indicators. User's Manual [online]. Retrieved 2020-07-28 from http://wits.worldbank.org/WITS/docs/TradeOutcomes-UserManual.pdf, la st accessed 2020/07/28. 


\section{Appendix 1}

HHI values for the Czech Republic and four other countries during the period of years 20092018

\begin{tabular}{lrrrrrrrrr} 
HHI & 2000 & 2001 & 2002 & 2003 & 2004 & 2005 & 2006 & 2007 & 2008 \\
\hline Czech Republic & 0.1947 & 0.2593 & 0.1889 & 0.5624 & 0.4137 & 0.1715 & 0.1957 & 0.3704 & 0.6414 \\
Hungary & $\mathrm{N} / \mathrm{A}$ & $\mathrm{N} / \mathrm{A}$ & $\mathrm{N} / \mathrm{A}$ & 0.4898 & 0.5145 & 0.4542 & 0.7166 & 0.5605 & 0.8196 \\
Poland & 0.1076 & 0.9594 & 0.1773 & 0.1305 & 0.8198 & 0.1714 & 0.9674 & 0.1391 & 0.2937 \\
Slovakia & $\mathrm{N} / \mathrm{A}$ & $\mathrm{N} / \mathrm{A}$ & 0.3449 & 0.1699 & 0.1841 & 0.6588 & 0.7656 & 0.8412 & 0.9468 \\
Slovenia & $\mathrm{N} / \mathrm{A}$ & $\mathrm{N} / \mathrm{A}$ & $\mathrm{N} / \mathrm{A}$ & $\mathrm{N} / \mathrm{A}$ & $\mathrm{N} / \mathrm{A}$ & $\mathrm{N} / \mathrm{A}$ & $\mathrm{N} / \mathrm{A}$ & $\mathrm{N} / \mathrm{A}$ & 0.1045 \\
\hline
\end{tabular}

Source: OECD (2020d), own data processing

\begin{tabular}{lcccccccccc} 
HHI & $\mathbf{2 0 0 9}$ & $\mathbf{2 0 1 0}$ & $\mathbf{2 0 1 1}$ & $\mathbf{2 0 1 2}$ & $\mathbf{2 0 1 3}$ & $\mathbf{2 0 1 4}$ & $\mathbf{2 0 1 5}$ & $\mathbf{2 0 1 6}$ & $\mathbf{2 0 1 7}$ & $\mathbf{2 0 1 8}$ \\
\hline Czechia & 0.4440 & 0.3075 & 0.3039 & 0.3699 & 0.1915 & 0.2367 & 0.1925 & 0.1794 & 0.1482 & 0.1423 \\
Hungary & 0.6423 & 0.8584 & 0.8148 & 0.7515 & 0.3197 & 0.1883 & 0.1870 & 0.4259 & 0.3286 & 0.8144 \\
Poland & 0.3721 & 0.5341 & 0.5963 & 0.6469 & 0.7532 & 0.4475 & 0.4680 & 0.4426 & 0.4837 & 0.5445 \\
Slovakia & 0.5751 & 0.4088 & 0.9477 & 0.6567 & 0.8020 & 0.3188 & 0.1850 & 0.2707 & 0.2051 & 0.2524 \\
Slovenia & 0.1390 & 0.2298 & 0.2350 & 0.5421 & 0.3610 & 0.2181 & 0.1737 & 0.1461 & 0.1235 & 0.1861 \\
\hline Source: OECD $(2020 d)$, own data processing & & & & & & &
\end{tabular}

